Portland State University

PDXScholar

$1-1-2011$

\title{
Couples Therapy: Gender and Sexuality in The Sun Also Rises
}

Jacob Michael Montie

Portland State University

Follow this and additional works at: https://pdxscholar.library.pdx.edu/open_access_etds Let us know how access to this document benefits you.

\section{Recommended Citation}

Montie, Jacob Michael, "Couples Therapy: Gender and Sexuality in The Sun Also Rises" (2011).

Dissertations and Theses. Paper 175.

https://doi.org/10.15760/etd.175

This Thesis is brought to you for free and open access. It has been accepted for inclusion in Dissertations and Theses by an authorized administrator of PDXScholar. Please contact us if we can make this document more accessible: pdxscholar@pdx.edu. 


\title{
Couples Therapy:
}

Gender and Sexuality in The Sun Also Rises

\author{
by \\ Jacob Michael Montie
}

A thesis submitted in partial fulfillment of the requirements for the degree of

\author{
Master of Arts \\ in \\ English
}

Thesis Committee:

Joel Bettridge, Chair

Marie Lo

Hildy Miller

Portland State University

(C) 2011 


\begin{abstract}
"Isn't it pretty to think so?" The ambiguity of this question, posed by Jake Barnes in the last line of The Sun Also Rises, is a reflection of the novel's evolving definition of what constitutes a relationship. As the focus of Hemingway criticism has slowly broken from tired discussions of misogyny a space has opened for considering the complex ways his writings address questions of gendered identity. Through this lens critics have asked exactly what kind of man and women Jake Barnes and Lady Brett Ashley represent. For decades critics and scholars have viewed this final line as having a negative connotation, signifying the death of love not only in the novel, but in the era. However, this reading fails to take into account the evolving gender roles the Brett and Jake represent. My essay looks at the novel's protagonists not simply as Brett or Jake, but also as Brett and Jake. Through this lens it becomes clear that Hemingway's portrayal of these characters is not one of the "bitch-goddess" and a defeated male, but of two people who, through their rapidly evolving gender roles and sexuality, are uniquely suited to be side by side when the rubble of the fiesta comes crashing down around them, not merely as friends, but as the only relationship that can truly exist.
\end{abstract}


Dedication

This thesis is dedicated to my father:

John C. Montie

Who could have moved mountains but chose to raise a family instead. 


\section{Acknowledgements}

This thesis owes a debt of gratitude to the entire English department at Portland State University but most specifically Professors Joel Bettridge, Marie Lo, Hildy Miller and Amy Greenstadt. Without their knowledge, tutelage, and willingness to work with someone who was at times in way over his head, this thesis would never have come to fruition.

Thank you. 


\section{Table of Contents}

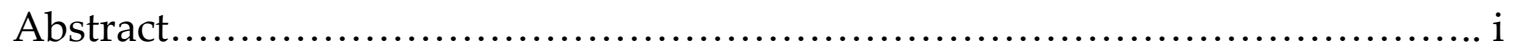

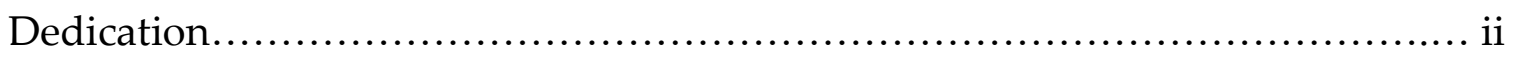

Acknowledgements...................................................... ii

Couples Therapy: Gender and Sexuality in The Sun Also Rises................... 1

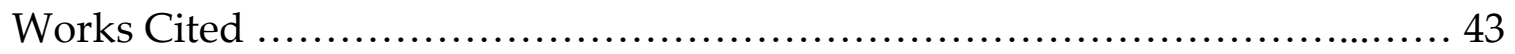

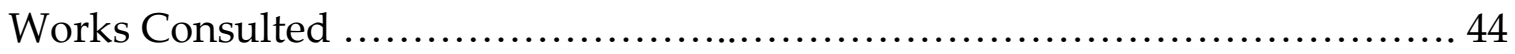


"Isn't it pretty to think so?" The ambiguity of this question, posed by Jake Barnes in the last line of The Sun Also Rises, is a reflection of the novel's evolving definition of what constitutes a relationship. For decades scholars and critics have given this line a negative connotation, viewing it as Jake indifferently dismissing his and Brett's relationship. However, this reading is flawed because past criticism has overlooked the way in which Brett and Jake's evolving gender roles make them uniquely suited to be side by side at the end of the novel. When looking at the novel not as a critique of the incapability of love in the post-war era of the 1920's but as a proving ground for the ways in which the breaking of traditional Victorian Era ideas of gender and sexuality can bring people together, it becomes apparent that Jake's last line is not an indictment of failure, but a proposal that his focus has switched to an unwritten future.

Early scholarship on The Sun Also Rises focused on Lady Brett Ashley and Jake Barnes as separate entities rather than as two people who are inextricably tied to a course that leads them together. In treating Brett and Jake as mutually exclusive entities critics and academics alike have missed a golden opportunity for deciphering some of the deeper meanings found within the text. To treat Brett and Jake as Brett or Jake downplays and destroys the fact that the two main 
characters of the novel's evolutions leads directly to them being able to be the only couple standing at the end of the novel. Their evolution from being two friends sharing a Parisian taxi ride, sitting apart from one another, sharing an intimate moment but unable to connect, to the bullfights where they finally find a way to share their private intimacy in a public setting, to the very end of the novel, where their public intimacy bypasses and encapsulates their private intimacy, allows them to be in each other's arms, rather than simply sharing a cab.

Hidden in decades of earlier criticism is the tale of two entities thoroughly wrapped up in the tumultuous gender trials of their time. Lady Brett Ashley marches through the novel attempting to gain traction in her life as she struggles to come to grips with her role as a modern woman, unshackling herself from the Victorian ideals of the past. Jake Barnes, for his part, spends the novel transitioning from a more macho traditional masculine role that, after his emasculation during World War I, no longer works for him. In doing so he finds that he has evolved past the machismo displayed by other male characters, and even past that of the aficionados of Pamplona, into a man that, unlike any other, can calmly function through the epicenter of the fiesta while all other male characters lose their heads. This calm, coupled with Jake's acceptance and 
adoration for Brett, and her transcendent sexuality, is what allows them to finally come together at the end of the novel. The first section of this essay will attempt to move beyond the body of criticism which exists for both Brett and Jake to redefine their identities so they are no longer the emasculating woman and the damaged man, only then can we as readers hope to comprehend Jake Barnes' famous last words.

In his The History of Sexuality Michel Foucault, when talking about a gilded era of sexual freedom in the seventeenth century and its demise at the hands of Victorian ideals states that, "twilight soon fell upon this bright day, followed by the monotonous nights of the Victorian bourgeoisie. Sexuality was carefully confined; it moved into the home" (Foucault 3). For Foucault, at the beginning of the twentieth century the West was still entrenched in a sexually repressed world. This world placed sexuality within the domain of the private, rather than the public, thus creating a taboo for sexuality to be expressed in front of the public eye. He goes on to state that society has constructed specific rules to prohibit sexuality from the public sphere, especially with regards to women:

1. A hysterization of women's bodies: a threefold process whereby the feminine body was analyzed - qualified and disqualified - as being thoroughly saturated with sexuality; whereby it was integrated into the sphere of medical practices, by reason of a pathology intrinsic to it; whereby, 
finally, it was placed in organic communication with the social body... the family space... and the life of children" (Foucault 104).

This placement of women's sexuality as being merely contained within the private sector of home life, and for the sole purpose of procreation, removed women's ability to express publicly their desires, their longings and finally their sexuality. However, as the twentieth century sped onward past the battlefields of Europe a new set of ideals and meditations on what gender and sexuality could mean in a public sphere erupted. On the cusp of this eruption was Hemingway's Lady Brett Ashley. In The Sun Also Rises Lady Brett Ashley breaks through the confining nature of Victorian sexuality and thrusts herself into the public sphere, not only as a woman with a public sexual identity, which was a radical idea for the time, but as a woman who can occupy and share a place in the arenas of men. Though she is certain this is the path that she wants to traverse, Brett at times struggles mightily with her new role, but through her confrontations with these struggles finds herself, by the end of the novel, in a place where intimacy can coexist not only in the private sphere of the home but in much more public settings as well.

Unfortunately for Brett modern scholarship was slow to catch up to the sexual unshackling that she represents. For decades after the publication of The 
Sun Also Rises Brett was demonized by scholars as a token woman in a novel about men, or more scandalously as a whore penned by Hemingway's misogynistic bravado. Leslie Fielder critiques that, "Brett never becomes a woman really; she is mythicized rather than redeemed. And if she is the most satisfactory female character in all of Hemingway, this is because for once she is presented not as an animal or as a nightmare, but quite audaciously as a goddess, the bitch-goddess" (Fiedler 94). Fiedler maintains that it is Hemingway's bravado that will not allow Brett to ascend to the ranks of true femininity. As Fiedler continues we see that at least in this sense it is Hemingway's, not Brett's fault for being a portrait of a bitch, "[The] fate in Hemingway's imagination of all Anglo-Saxon women [is to be a bitch]. In him, the cliché of Dark Lady and Fair survives" and later, "in Hemingway such women are mindless, soft, subservient; painless devices for extracting seed without human engagement" (Fiedler 92). Fiedler forgives Brett for her transgressions against womanhood but not through any feat of her own. He forgives her simply because she was written by Hemingway and he could do no better.

This undercurrent of not trusting Hemingway's writing when it comes to women remains a constant theme throughout much of the critical history of the 
novel. However, scholarly and critical frustrations branch out from simply not trusting Hemingway, to finding folly with the merits of Brett as a character. Mark Spilka labels Brett as just as much of an emasculating device as the war itself. In speaking of the ear that Romero cut off of a bull and presented to Brett she "stuffs it far back in the drawer of the bed-table, and forgets about it" thus creating the idea that "the death of this bull was a communal triumph and his ear a token of communal strength; for Brett the ear is a private trophy. In effect, she has robbed the community of its triumph, as she will now rob it of its hero" (Spilka 42). By claiming that she is robbing the fiesta of its masculine hero, Spilka claims that she has emasculated the entire community, thus robbing them of their phallic victory over a bull who had slain one of their own. In doing so Brett not only defeats any chance of adding a redeeming female quality to the novel, she instead fulfills the prophecy of Edmund Wilson who labels her with great animosity as "an exclusively destructive force" (Wilson 46).

Much like the criticism of Hemingway that focused on him being a predictable and heartless misogynist has been derailed and rerouted over the last thirty years, so too has the criticism of Brett that viewed her as a carnivorous tramp. A landmark turning point in this criticism came with the publication of Wendy Martin's article "Brett Ashley as New Woman in The Sun Also Rises." In 
this article Martin puts forth the idea that Brett Ashley exists amongst the first wave of women breaking free from what Foucault saw as the public desexing of the western world and that she is placed inside a "shift in perception of gender following World War I. This redefinition of masculinity and femininity was not an abrupt rift in the cultural landscape but rather a gradual shifting of the ground on which the edifice of Victorian sexual identity was built" (Martin 47). The New Woman finds herself exhibiting publicly what was once a repressed sexual identity.

By entering the public sphere of work and commerce, the New Woman established herself as a viable entity in those domains. What followed was an entirely new way in which women took part in the social lives of men. By breaking down these closed doors the New Woman of the 1920s ushered in some of the most radical social change of the era, and opened the path for further expansion of male and female equality that would come later in the century. Hemingway understood or was at least fascinated by this shift and created Brett at a time when she would have been seen as an early literary explorer of these new grounds. As Martin puts it “The new woman's radical challenge to the traditional social structure is seen in Lady Brett Ashley, who has stepped off the pedestal and now roams the world. Entering the public sphere without apology, 
she dares to frequent places and events previously off limits to her" (Martin 50). These places, such as frequenting bars in Paris and Pamplona, or sitting with the men as they take in the bullfights of the fiesta, were once regarded as places where only men could establish domain. Brett's challenge to these rules is seen in the fact that not only is she a central character to this story, she is the central character to the novel, as is evidenced by the original opening lines of the novel which stated "This is a novel about a lady. Her name is Lady Ashley" (Hemingway 7).

Almost immediately upon entering the novel Brett attempts to establish herself as "one of the guys." This is not Brett attempting to cross over to the male side of the gender; rather it is Brett's first attempt in the novel to blend the social barriers between men and women, making them easier to cross. Brett shows up at the same bar as Jake with a group of young men and begins to dance. Jake stands at the bar chatting with Robert Cohn when Brett comes up and inserts herself into their conversation:

Brett came up to the bar.

"Hello, you chaps."

"Hello, Brett," I said. "Why aren't you tight?"

"Never going to get tight any more. I say, give a chap a brandy and soda" (TSAR 29). 
Here, Brett's usage of the word "chaps" indicates a familiarity with both the scene and the people she is conversing with. She is both free and at ease at the bar which, prior to World War I, would have been a place reserved almost entirely for men. More indicative of her status with this group is the way that she refers to herself as a "chap" as well. Chap, being a friendly title given from one man to another, indicates that she is not only willing, but able to include herself in this act of male bonding. However, this is not an attempt at crossing over the lines of gender from a female to male. Instead, Brett is participating in the blurring of female and male roles that occurred during this era.

A few paragraphs later Jake will describe her attire for the evening in full detail. Her attire includes a "slipover jersey sweater and a tweed skirt" (TSAR 30). As Wendy Martin points out this type of female apparel was designed for a new era of woman, "gone are the long skirts, bustles, and constricted waists: New clothes designed by Coco Chanel and Erte are intended for movement. The short skirts and light fabrics of the new fashions for women shocked traditionalists" (Martin 50). For Brett these clothes emphasize her "curves like the yacht of a racing hull" and produce a more voluptuous female figure, which would seem to indicate that she is playing up her feminine sexuality, but at the same time Jake states that "her hair was brushed back like a boy's. She started all 
that" (TSAR 30). Brett's look simultaneously displays her as sensuously feminine - compare this to Georgette, the prostitute Jake Barnes picks up earlier in the novel, about which he says "with her mouth closed she was a rather pretty girl" (TSAR 23) - and as a disruption of old and now forgotten ideas of how a woman should look in public. Brett is an active participant in blending the boundaries between female and male social roles; from her appearance in bars traveling with a group of men to her dress and even giving herself a male term of endearment for a title she clutters up the long-held social strata in an effort to be on equal footing in the arenas that she chooses.

Not only does she look profoundly sexy while denouncing this old feminine look, but as Jake states "she started all that" meaning that not only is she caught up in the middle of this radical change, but she is at the tip of the spear of fashion for women of the era. Combine her usage of "chap," with the detailed description that Jake paints for us, and almost as soon as Brett comes into the novel we know that she has ascended to a certain new place in the female mystique. She caravans across Paris with a crowd of men, dances with reckless abandon, and then draws herself into a conversation with two men by associating herself with their side of human sexuality. Hemingway's first portrayal of Brett is one of great deviation from the norm of the past, and it sets 
the tone for the rest of the novel where she is depicted time and again as a woman at ease in the world of men, and it is this ease in situations with men that puts her in position to follow what Foucault says and enter into this realm of public intimacy that would have previously been off limits to her.

Much later in the novel Brett, Jake and the others are spectators at the bullfights in Pamplona. The shocking turn of events here is not so much that Brett is a spectator at the bullfights, while this would traditionally be classified as a male spectator sport, what is shocking is the way in which Brett not only attends but engages in and understands the bullfights. In order for Brett to continue her transformation so that her and Jake can truly come together at the end of the novel she must not be squeamish at the sight of the gore inside the arena because it is in the arena that her and Jake's public intimacy is at its most spectacular. Instead Brett must be relaxed, engaged and entranced by what many have called a gruesome spectacle, and she is.

Before the first bullfight Jake warns Brett that she shouldn't watch when the bulls hit the horses. Jake does this in an effort to save Brett from having to recoil from the brutality of the event. After the gang returns from the bullfight Jake questions Brett about her reactions:

"How did it go?" 
“Wonderfully! Simply perfect. I say it is a spectacle!"

"How about the horses?"

"I couldn't help looking at them."

"She couldn't take her eyes off them," Mike said. "She's an extraordinary wench."

"They do have some rather awful things happen to them," Brett said. "I couldn't look away, though."

"Did you feel alright?"

"I didn't feel badly at all" (TSAR 169).

Initially worried about her reaction to the violence Brett finds that she has the acumen to watch the bullfights in their entirety. She sees the bullfights as a spectacle that she thoroughly enjoys. Where Jake, who is an aficionado about bullfighting expects Brett to be disturbed or taken aback by the carnage that unfurls inside the arena she handles it much as he does, by understanding the beauty of it, and does not "feel badly at all."

In fact, her reaction is manifestly opposite from that of one of the male characters: Robert Cohn, who Mike Campbell proclaims was "quite green." Robert, who thought that the bullfight was going to be boring, is the character whose stomach cannot handle the spilling of blood brought on by the bulls and because of this he is kidded and momentarily ostracized from the group. Brett, on the other hand can handle the macabre details of it all because she has undergone this transformation from Lady Ashley to Brett, a masculine name attached to a woman, where she finally is successful in blurring the lines between 
the sexes, giving them a nebulous quality which allows her to float freely in this new grey area amongst her male companions. It is not that she is becoming a man; rather it is that she is a woman who has traded in the chains of Victorian feminine formality for a life spent next to men doing manly things in masculine environments, she maintains her "curves like the hull of a racing yacht" but moors them in the heart of the fiesta, the arena, rather than spending her time withering away in the home of her estranged husband. In fact it is this ability to "do manly things" that allows Jake the opening to introduce her to the true beauty of the bullfights, cementing their most publicly intimate scenes and allowing their friendship to take its next step. Not only does she enjoy her time at the bullfights, but she respects the action, and before the next bullfight she proclaims that she wants "to sit down below, next time" so that she can be closer to the spectacle itself and where she can sit by Jake and take in his aficionado knowledge so that she too can fully understand the event not as an act of bloodlust, but one of great muscular power and grace. Jake too finds himself in an evolutionary state. Brett and Jake are both struggling against the traditionally defined gender tropes of the day. Where Brett thrusts herself into the public stage, fighting to be seen on equal footing with the men around her, Jake finds himself on a similar path. Jake is already socially 
accepted as a male, however, after his wounding during World War I his masculinity exists on different terms than that of the men around him. Finding that traditional male gender roles of sexuality and machismo no longer apply to him Jake struggles with his attempt to find a masculinity that works for him, one that will ultimately allow him to be with Brett. He will find this masculinity amongst the world of the aficionados in Pamplona, but where their masculinity and the knowledge that comes with it allows him to get closer to Brett it will ultimately be the evolution of his masculinity, a masculinity who cares not for the traditional female roles that Brett is trying so tirelessly to rid herself of, that will allow him to rest comfortably against Brett in a cab in Madrid.

The first time we see Jake Barnes interact with a woman is when he decides to attract the attention of a prostitute while sitting down for a drink after having parted ways with Robert Cohn. Jake's decision to have the prostitute accompany him for the evening represents, on a very basic level, Jake's attempt at reclaiming his masculinity after his wounding in World War I. For him, the ability to entertain a woman represents a very fundamental male activity that should come naturally given his status as a man. He attracts her attention "because of a vague sentimental idea that it would be nice to eat with some one" 
(TSAR 24). In other words, and as he says later, it had been a long time since he ate with a woman and figured it would be worth a try.

Unexpectedly Jake runs into a group of his friends at the restaurant they head to and he is forced to incorporate Georgette into the group, which he jokingly does by announcing her as his fiancé. When later the group ends up at a dance club Jake pays it no mind when Georgette is asked to dance by someone else and then as he is standing in the doorway Brett arrives. Quickly the two exit the club and he leaves fifty francs for the girl he only a short time ago had entertained. Georgette exists only to effectively work as a trial run to see if he has fully reclaimed his masculinity. With that seemingly secured - and I say seemingly because, as the cab ride will prove, Brett and Jake have not, at this early stage in the novel, evolved to the point where they can be more than just friends - Jake makes the decision to pursue the woman that he will, for the first time in the novel, tell he loves: Lady Brett Ashley.

The act of picking up a prostitute begins a series of adventures that Jake Barnes takes in the novel in an attempt at redefining his own masculinity, transitioning from traditional male bravado to a more centered male persona, a persona that ultimately can find itself in the arms of Brett Ashley. He cannot reclaim his masculinity as it once was, because, as we will see in the novel, this 
masculinity proves ineffectual in securing the love of Brett, but he can reclaim it and shape it into something far more useful and worthwhile. This is not simply a boys will be boys or real men do manly things narrative; no, the activities that Jake Barnes partakes in build in an ever ascending arch until the crescendo of the bullfights where Jake Barnes adroitly and confidently materializes once more as a man who has shaken off his early fears about living life as a man without man's most obvious instrument, into a calm, relaxed, and competent male who, unlike the men with fully functioning genitalia, is ultimately perfectly attuned to love Brett.

Jake's fishing trip with Bill is not the first adventure that Jake has after picking up a prostitute, but it is the first one after the scene with Georgette that is detailed so lavishly and is so clearly a stepping stone for him in his process of masculine retrieval. During this excursion with Bill, especially while fishing, the prose becomes elevated and less terse than much of the novel. Hemingway clearly paints a picture of a man at home on the river. Jake's fishing adventures pit him against a creature that Hemingway has great respect for and you can see it in the prose as he describes the trout as making a "lovely arc" out of the water and being "beautifully colored" (TSAR 124). But the prose becomes its most beautiful while Jake is pitted directly against the fish itself: 
I did not feel the first trout strike. When I started to pull up I felt that I had one and brought him, fighting and bending the rod almost double, out of the boiling water at the foot of the falls, and swung him up and onto the dam. He was a good trout, and I banged his head against the timber so that he quivered out straight, and then I slipped him into my bag (TSAR 124).

Here Jake's skill is portrayed as being profound. Jake picks a spot in the river at the foot of a small waterfall where he knows the trout will congregate and his chances of hooking one are significantly higher. Jake reels in the fish with a fantastic display of skill and grace and when the job is done he bangs his head on a log and easily slips him into his bag as if, after this detailed description of his battle with nature, it was no difficult task at all.

It is especially important that Jake is a skilled fisherman. This is the first sense we get of him being a master or knowledgeable of a craft and by portraying the fact that Jake is particularly skilled of a traditionally masculine hobby, sets the stage for his ascension as an aficionado in Pamplona. After he has finished fishing he carefully cleans the fish and packs them away in a bag between ferns so that they are not ruined by the heat or by being inside the bag, something that an expert angler would know how to do. Hemingway portrays Jake as one who understands the complexities and intricacies of what at the time was viewed as a thoroughly male spectacle. Had he and Bill gone fishing and he 
not caught anything, then the effect of the trip on his masculinity would be minimal to nil. However, Jake is a skilled angler, one who picks a spot in the stream where he can maximize his skills, and lets him take it from there.

However, what is far more important is the way this particular scene on the river acts as a precognitive for the events of the fiesta where the true reclamation and modification of Jake's masculinity is finalized. On the Irati River Bill acts as a counterexample of Jake's new constructions of his masculinity. Jake chooses to fish with a rod and reel while Bill chooses to fish with a fly rod, which is traditionally considered to be the more difficult of the two styles of fishing. Each of their fishing exploits reveals something about the place of their masculinity:

Bill sat down, opened up his bag, laid a big trout on the grass. He took out three more, each one a little bigger than the last, and laid them side by side in the shade from the tree. His face was sweaty and happy.

"How are yours?"

"Smaller."

"Let's see them."

"They're packed."

"How big are they really?"

“They're all about the size of your smallest" (TSAR 125).

Jake, who Bill calls a "lazy bum" after learning that he caught all of his fish on a reel, catches more fish than Bill, however his are much smaller. This shows the 
divergent views on their masculinity. While Bill chose to go downriver away from the dam to calmer streams it is Jake who decides to wade in at the strongest point of the river and test his skills amongst the rapids. In this way it is Bill who is the lazy bum. Jake has taken more fish in a more challenging section of the river and the scene acts as a precursor for Jake's establishment as a man who can remain calm throughout riotous events later in the novel. For it is while Bill and the others lose themselves and devolve into chaos that Jake is able to keep his cool amongst the mercurial torrent of the fiesta.

As a last example of the evolution of Jake Barnes' masculinity and as the last chronological moment in the narrative before the fiesta it is fitting that we get this important glimpse of Jake's new calm under pressure right before the trip back into Pamplona. Earlier in the novel, when thrust into chaos in the bars of Paris, Jake Barnes would complain of headaches or of having to work in the morning and head home to avoid the turbulence of the evening. As a skilled angler we are able to see Jake calm in the face of the torrent. This ability to maintain his focus and skill as a fisherman ends up translating directly to the fiesta where Jake is most obviously the one male character who is able to keep their head and remain centered as the world erupts around them. 
That Jake has, on the river, developed his masculinity into something recognizable by those around him is evident upon his arrival in Pamplona. From his first conversation with Montoya we are given the indication that in this place Jake Barnes is the master of the situation. It is quickly revealed that while Bill might be a better fisherman, Montoya, who acts as the guardian of the aficionados can quickly spot that Bill is not as knowledgeable as Jake with regards to bullfighting:

"Your friend, is he aficionado, too?" Montoya smiled at Bill. "Yes. He came all the way from New York to see the San Fermines." "Yes?" Montoya politely disbelieved. "But he's not aficionado like you."

He put his hand on my shoulder again embarrassedly. "Yes," I said. "He's a real aficionado."

"But he's not aficionado like you are" (TSAR 136).

Jake Barnes might not be able to get an erection, but he has the capability to fully understand and truly enjoy the bullfights. To men like Montoya this means far more than the status of his penis. Whether or not Montoya knows of his injuries is superfluous, what is important to Montoya is that Jake is a possessor of aficion, and within the framework of the novel it is this possession of aficion that supersedes everything. Being an aficionado during the fiesta in Pamplona gives you access to very specific conversations and insights into the world of the fiesta. 
Montoya is one of the gate-keepers of this cult of the aficionado, and Hemingway goes on to explain Montoya's guardianship:

Aficion means passion. An aficionado is one who is passionate about the bull-fights. All the good bull-fighters stayed at Montoya's hotel; that is, those with aficion stayed there... Photographs of bull-fighters who had been without aficion Montoya kept in a drawer of his desk. They often had the most flattering inscriptions. But they did not mean anything. One day Montoya took them all out and dropped them in the waste-basket. He did not want them around (TSAR 136).

Belonging to this club of aficion is Jake Barnes and it is portrayed as a club for men to be amongst men who share this passion for bullfighting. Much like Jake and Bill share a moment as skilled fishermen, Jake will share moments not only with Montoya as a peer, but also with the bullfighter Romero, whom both Montoya and Jake feel is a bullfighter who possesses a purity of aficion. Aficion, then, and the possession of it, becomes the book's definition of this elevated masculinity. Much like Romero can keep his calm and focus while in the center of the arena, Jake can keep his composure and his wits while in the middle of the fiesta and this is the defining characteristic that allows him to finally bridge the gap between public and private moments that will inevitably allow Jake to be alone with Brett at the end of the novel. 
Montoya is not only a gatekeeper - or innkeeper - to the club of the aficionados, but also their guardian, offering those who possess aficion a safe place away from the eye of the public, those who would abuse them and perhaps ruin them. Because of his status as an aficionado Jake Barnes is allowed to stay at the Hotel Montoya every year, and he is given the leeway to bring his friends, despite the fact that they are not aficionados, to stay there as well. Jake's possession of aficion acts as a stand-in for his lack of functioning genitalia. Without Jake none of the others in the group would begin to fully comprehend the spectacle of Pamplona outside of the fact that you are able to drunkenly wander the streets of the city for the duration of the fiesta.

Where Montoya is the gatekeeper to the club of the aficionados, Jake Barnes is the gatekeeper to truly understanding the bullfights for all of his friends. It is only through Jake Barnes that Bill, Robert, Michael and most importantly Brett can begin to comprehend the violent beauty that is bullfighting. Even Bill, who Jake vouches for as an aficionado, needs to have things explained to him. Jake is happy to introduce him to the spectacle:

"What's it (the unloading of the bulls) like?"...

"It's pretty good," I said. "They let the bulls out of the cages one at a time and they have steers in the corral to receive them and keep them from fighting, and the bulls tear in at 
the steers and the steers run around like old maids trying to quiet them down."

"Do they ever gore the steers?"

"Sure. Sometimes they go right after them and kill them."

"Can't the steers do anything?"

"No. They're trying to make friends."

"What do they have them in for?"

"To quiet down the bulls and keep them from breaking their horns against the walls, or goring each other" (TSAR 138).

Jake immediately shows himself as the most knowledgeable of the party when it comes to bullfighting. As an aficionado Jake Barnes is seen by the other aficionados, and by the members of his party, as the ultimate liaison between their lack of knowledge, and enjoyment of the festival's main attraction. In Pamplona Jake Barnes becomes the unquestioned leader of the group. It is this heightened and hyper masculinity of aficion that grants him access to the side of the fiesta that most participants never see: staying at the Hotel Montoya, conversing with Montoya himself, meeting Pedro Romero in his room. It is also his possession of aficion that gets him invited to the table with Romero so that he can speak with the bullfighter and a reporter about the nature of the bulls.

During this conversation Romero repeatedly defers to Jake's impression of the bulls before revealing his own condemnation or approval. Romero is regarded as the greatest bullfighter at the fiesta. Montoya, upon receiving word that the American ambassador wants to meet with Romero, cares not that it 
would be a wonderful honor for the young bullfighter to meet such an esteemed man, but that he might be spoiled “People take a boy like that. They don't know what he's worth. They don't know what he means. Any foreigner can flatter him. They start this Grand Hotel business, and in one year they're through" (TSAR 176). The guardian of the aficionados cares this much about this bullfighter who, in his conversation with a critic, will wait to hear Jake's opinion before he announces his own to the world as if he is afraid that his might differ from the American aficionado:
"Have you seen the bulls for to-morrow?" the critic asked me.
"Yes. I saw them unloaded."
Pedro Romero leaned forward.
"What did you think of them?"
"Very nice," I said. "About twenty-six arrobas. Very short horns. Haven't you seen them?"
"Oh, yes," said Romero.
"They won't weight twenty-six arrobas," said the critic.
"No," said Romero.
"They've got bananas for horns," the critic said.
"You call them bananas?" asked Romero. He turned to me and smiled. "You wouldn't call them bananas?"
"No," I said. They're horns all right."
“They're very short," said Pedro Romero. "Very, very short. Still, they aren't bananas" (TSAR 178 -9).

Romero insists not one but two times on asking for Jake's opinion before pressing his own into the conversation. Through this Jake proves that he is on 
level with the bullfighter who possesses the most aficion, and in doing so he completes the journey he first undertook by picking up a poule. Jake, who once turned away the hand of a prostitute because of both his wounds and his uncertainty about his masculinity, has gained acceptance at the table of the aficionados, who are depicted as those most in tune with their masculinity. The once emasculated man has been remasculated through this interaction as if his membership in the club of aficion allows one admittance into the club of masculinity, regardless of wounds previously sustained. In effect, the fiesta, and his knowledge of bullfighting, permits Jake Barnes to reaffirm his own masculinity and proceed towards the pivotal scenes in the novel where Brett and Jake interact in the arena. This is why he can navigate the explosions and outbursts between Mike and Cohn, Cohn knocking him unconscious, and Brett's decision to be with Romero with ease and why during his time at San Sebastian he seems completely in tune with the world around him. In his conversation with Romero he has regained the masculinity he tangibly (not physically) lost in the war, and after its reclamation he finds himself more sturdy under the fire of the chaos that surrounds him.

Most importantly it is imperative that he has regained his masculinity for it is the sense of equilibrium that this reclamation has given him that allows him 
to level-headedly utter the famous final lines of the novel. Much like Jake chose the easier method of fishing and plied that trade in an uproarious part of the river, and Bill chose a much more difficult method, Jake's possession of aficion, a trait which is regarded as a higher form of masculinity, allows him to navigate the fiesta with the least amount of chaos. While he has reclaimed his masculinity, he is still a special case, his wounding has given him access to a clarity that none of the men in the novel can fully appreciate or understand. Jake's wounding and subsequent journey back from the brink of male annihilation have given him the ability to interact directly with Lady Ashley unlike any other man. This is the reason why Brett wires Jake at the end of the novel, because nobody understands or is more level headed than he. While the social world that they constructed burned to cinders around them, Jake was the one who was able to maintain his composure amongst the chaos of Pamplona, and because of this he is in fact her "one true love" and this is the reason why it is Jake, not anyone else, who is sitting with her at the end of the novel.

Finally, after entertaining a prostitute, reclaiming his lost masculinity and finding his requests for time spent alone together rebuffed by Brett, Jake realizes that it is not a lack of a fully functioning penis that prevented him from being with her. While on the river with Bill and in conversations with Montoya and 
Romero Jake finds himself coming to a much clearer understanding of not only his masculinity - his possession of aficion - but of where he and Brett can finally come together. Their connection does not require the traditional masculinity that all of their friends possess, the kind that sends them off into the bustle of the fiesta without composure. What their connection requires is something greater, and while sitting next to Brett in the arena he realizes that his passion for the bullfights will allow the two of them the public intimacy that his colleagues cannot achieve and this will become the stepping stone that allows them to come together. With Brett adopting fully to her New Woman persona, and Jake having transitioned away from the masculinity of his friends to this new masculinity of the aficionado, we as readers can now trace Brett and Jake's, not Brett or Jake's progression through the novel.

It is when Brett and Jake leave the dance club that we learn that her public persona and her intimate persona are vastly different. As soon as Brett and Jake have a chance she suggests that they leave together. After getting in the taxi where Brett has Jake tell the cabby to just "drive around" Brett's public persona immediately shatters in the safety of the cab where she utters the last lines of the third chapter "Oh, darling, I've been so miserable" (TSAR 32). The fact that Brett's public rapport is so quickly shelved for a tone of need is telling, and will 
become a theme throughout the novel. Brett is only willing to open up her internal emotions when in close proximity of Jake and no one else, we will see this pattern repeated numerous times on Jake's doorstep, in a café in Pamplona, while walking the streets of Pamplona, and again in Madrid at the novel's finale. It is this initial private intimacy that establishes that Brett and Jake are, despite his physical limitations, in love. The "miserable" feeling that Brett has kept bottled up inside is only able to be spilled into conversation in Jake's singular presence. As the scene progresses we see firsthand the passion that both encapsulates and torments them. The lack of physical intimacy is a constant barrier to their happiness, but despite that barrier they know they cannot exist apart from one another:

"It is good to see each other."

"No. I don't think it is."

"Don't you want to?"

"I have to" (TSAR 35).

Despite the pain of not being able to be "truly" together in the fully romantic sense of the word Brett and Jake find that they need to see each other if only to reconfirm that love is a painful affair. After this exchange they sit in the cab "like two strangers" and ride in a deep quiet. However, the distance between them cannot last and as they pull up to their destination Brett asks Jake for a favor that 
is simply "kiss me just once more before we get there" (TSAR 35). At this point in the novel their intimacy can go no further, despite the fact that they tell each other that they are in love. In spite of this, Jake's touches turn her "all to jelly" and she has to have one final kiss. The intimacy shared in the cab, while brief, gives us insight into the world that Brett and Jake share. They desperately need each other; yet in their early attempts to deal with that intimacy they are stuck between two immovable objects: their professed love for one another and their inability to express that love physically. Neither of these is going anywhere, and they spend the rest of the novel trying to find a way to coexist between the two.

The second private moment I would like to speak on is spent in Jake's bedroom a little later on in the novel. In this scene Jake is showering when Brett and the Count come to call. Jake goes into his bedroom and feels "tired and pretty rotten." Brett sends the Count away to go get some champagne. While he is gone Jake lays on the bed as Brett strokes his head and calms him down. There is a jump in the narrative where they are sitting on the bed together and she finally says "Do you feel better, darling? Is the head any better?" to which he responds "It's better" (TSAR 62). Now, one can speculate as to what happens in this leap in the narrative, but it would be just that: speculation. What this essay is concerned about is the about face that Jake's mood makes when they are finally 
alone together. Jake will go on to suggest anything from living together, to going away on a vacation, anything to get them alone together, but their relationship has not yet evolved to the point where these escapes to the countryside are possible. Both Brett and Jake are still dealing with their respective evolutions and have not yet come to that climax. The singularly spectacular instance of this moment is that whatever the rotten feeling Jake has is reduced to nothingness with Brett at his side. Brett's presence alone is enough to lighten the burden of Jake's ailments and to produce a rejuvenating effect upon him. Brett, like Jake in the taxi before, has already proven the ability to satiate the nervous energy that surrounds them as they progress towards the climactic moments of the novel. But it isn't these private moments of closeness that will ultimately allow for Brett and Jake to be together, it will be their ability to share moments that publicly mirror the ones they share privately that will finally allow them to evolve from sitting apart from one another in a Paris taxi to arm in arm in Madrid. The possibility exists for the scholars and critics to misconstrue the way that The Sun Also Rises chooses to view love, or doubt that by the end of the novel that love can truly exist in the novel. I can see where they might get this idea, with the many men that Brett takes to her bed throughout the novel, none of 
them being Jake Barnes; there is some wiggle room in deciding whether their potential for true love exists or is simply a mirage.

In one of these occasions where the idea of love in the novel seems to rest on shaky ground Jake is actually the facilitator of one of Brett's trysts. After a particularly disastrous row between Mike and Robert Cohn, Jake and Brett find themselves alone walking through the ancient fortifications of Pamplona. During this conversation Brett announces that she has fallen for the bullfighter Romero, and that it is hopeless for her to resist. Jake does his best to dissuade her from her feelings, to insist that going after Romero is the wrong course of action.

However, in realizing that he cannot convince her otherwise, and in knowing that he cannot act as a sexual distraction from her desire for Romero, he leads her to the bullfighter to initiate their romance.

Mark Spilka, in his article, "The Death of Love in The Sun Also Rises" states that in using Jake to facilitate her tryst with Romero that Brett is simply using Jake as a means to set up her next sexual conquest:

...so has Brett reduced him to a slavish pimp. When she asks for his help in her affair with Pedro, Barnes has no integrity to rely on; he can only serve her as Cohn has served her, like a sick romantic steer. Thus, for love's sake, he will allow her to us him as a go-between, to disgrace him with his friend, Montoya, to corrupt Romero, and so strip the whole fiesta of significance (Spilka 42). 
Spilka argues that Jake, like many of the other men in the novel, is a pawn that Brett moves when she sees something she desires. Jake is a tool at her disposal, another notch in her belt of castrations, and in helping Brett he accelerates the death of love in the novel.

But Spilka misses a very simple, yet important part of the dialogue. Jake, under the idea that he is not physically capable of fulfilling Brett's carnal desires, is willing to forgive Brett for her many companions. Jake introduces the two not because he has pimped out his heart to her, but out of compassion for his friend who is shaking with trepidation while sitting on the ancient fortifications of the city. Jake is not serving Brett as Cohn served her. He is not serving her at all. She never asks him for his help in their affair; Jake offers his help saying "what do you want me to do?" and then the response comes, "come on," Brett said. "Let's go find him" (TSAR 188). Jake offers his help willingly because he feels that this might ease the trembling inside of her. There is a vast gap between acting as a pimp, and helping out a friend in distress, and Jake does not cross it. In thinking that this romance with Romero might be of some help to her, Jake leads Brett towards her desires.

What truly separates Brett and Jake from the other romances in the novel: their ability to publicly recreate the intimacy that they share privately. While it is 
never explicitly said in the novel it would be foolish to think that Brett does not share private intimate moments with the other men in her life. But what we do see in the novel is that public intimacy is only shared between Brett and Jake. This is what separates Jake from Robert Cohn and Mike Campbell, who both "behave very badly" in public scenes. Robert Cohn, for instance, spends his time at the fiesta following Brett not only with his feet but with his eyes, ogling her from across tables and arenas. Instead of reveling in the party that is the fiesta he is a love struck man-child who rarely speaks unless he is spoken at directly. He is not there for the party, he is there because Brett is there, and because they shared what he thought was a special moment in San Sebastian. He cannot separate the private moments that Brett and he shared in San Sebastian from the very public environment of the fiesta, and because of this he becomes a scorned ex-lover rather than a friend. This is the most important difference between him and Jake whom Brett shares a very true and real emotional bond with.

Jake has these very sincere and intimate moments with Brett in what is perhaps the least intimate of theaters: the bullfight. Jake knows how to translate the very intimate moments that they share in private into a public intimacy that she does not share with any of the other character in the novel. Nowhere is this more explicit than when Jake helps Brett to understand the bullfights themselves. 
At the unloading of the bulls Jake and Brett sit next to each other in the stands. Jake begins Brett's indoctrination to bullfighting by attempting to explain the intricacies of a bullfight that make it beautiful:

“My God, isn't he beautiful?" Brett said. We were looking right down on him.

"Look how he knows how to use his horns," I said. "He's got a left and a right just like a boxer."

"No really?"

"You watch."

"It goes too fast."

"Wait. There'll be another one in a minute" (TSAR 144).

It is this brief explanation that gives Brett the insight to immediately see the bull's movements, "'I saw it,' she said. 'I saw him shift from his left to his right horn'" (TSAR 144). Thus begins Brett's indoctrination into the beauty of the bullfight. Amongst the tumult of the bullfight Jake explains so that Brett will see the true beauty in the spectacle. By doing this Jake brings Brett closer to him by sharing something with her that he has a true passion for, and in her growing excitement for the fighting they can communicate on a more intimate level publicly than any of the other characters, most obviously Cohn, can.

Later on Jake explains to her what makes Pedro Romero such a better bullfighter than the rest of the toreros taking part in the fiesta, "I sat beside Brett and explained to Brett what it was all about... so that it became more something 
that was going on with a definite end, and less of a spectacle with unexplained horrors" (TSAR 171). By showing Brett the beauty of bullfighting:

Romero never made any contortions, always it was straight and pure and natural in line. The others twisted themselves like cork-screws, their elbows raised, and leaned against the flanks of the bull after his horns had passed, to give a faked look of danger. Afterward, all that was faked turned bad and gave an unpleasant feeling. Romero's bull-fighting gave real emotion... (TSAR 171).

It is this real emotion that spills over from the arena floor into the stands. As Brett comes to appreciate Romero's purity of form she and Jake are able to come together like they never have before. As this New Woman, Brett not only finds herself in the bullfighting arena, a domain normally reserved for men, but she comes to an understanding of the bullfights, something that Jake's status as an aficionado accelerates, allowing the two to share a more dynamic public intimacy. Where they cannot be physically intimate they can have an emotional intimacy that attaches them even more affectionately than do the physical trysts she shares with the other men. This emotional intimacy supplants the physicality that they lack, enabling them to share something much more significant.

Jake indoctrinates Brett into bullfighting so that they can publicly share the intimacy that they have behind closed doors. He goes to these lengths so that they can share something in his world that he thinks is beautiful, so that she can 
understand it for all of its intricate and subtle beauty. Jake's public behavior mirrors his private in that he can find ground where he and Brett can be intimately linked through a common understanding of the beauty and passion of bullfighting. Where Cohn fails to make this transition from lover to friend, Jake is able to bridge the gap from private to public intimacy and because of this becomes the only character that Brett can truly love and be with. Brett and Jake can say they are in love as much as they want, and they do, but until they combine the positives of their private and public intimacy like they do at the bullfights they never could entertain the ideas that they do at the end of the novel, and it is this bridging of the gap that sets up the final scenes of the book. Eventually Brett will cast all other men aside, save for one: Jake Barnes. After Jake has not only recaptured but separated himself from the machismo of the other male characters into his new calm and centered masculinity while at the fiesta in Pamplona he takes a vacation down to San Sebastian to relax. Having finally proven to himself that he can not only reclaim but also reshape his masculinity so that it is stronger and more workable despite his physical limitations, his time there is spent truly at ease with the world around him. Jake's calm in San Sebastian is caused by two things: His removal from the chaos of the fiesta, "I wished I had gone up to Paris with Bill, except that Paris would have 
meant more fiesta-ing. I was through with fiestas for a while" (TSAR 236) and his working knowledge that he and Brett have finally had their shared moment in the sun. Yes, she is off with Romero, but in that regard Jake thinks that Brett is happy with him. That this knowledge becomes false later on is a mute point, what is important is that Jake knows where he and Brett stand, and just like his days in San Sebastian he has reached a calmness that is only extended through the final chapter of the novel.

It is this calm that explains Jake's reaction to the telegrams that he receives from Brett. The telegrams state that Brett is "really in trouble" and instead of exploding once more in comparison with the uproar at the start of the fiesta Jake is calm in his interactions with the waiter at his hotel, and in his telegrammed response Jake signs the wire with "love." Despite all of the troubles of the past scenes Jake can and I would argue for the first time, tell Brett he loves her and truly mean it. Unlike the postulations of Ellen Andrews Knodt who states, "that Jake on this second day at San Sebastian is taking a leisurely look around, noticing the features of the harbor, suggests that his decision to live without Brett is behind him" (Andrews Knodt 6). Jake hasn't decided to live without Brett, he merely thought her to be happy. When this proves not true his first response to 
her is to make sure that she knows that not only will he immediately be on his way to her side once more, but that he loves her.

But not even Romero, the greatest of the bullfighters, possesses the right type of masculinity to stay with Brett. When we get to Madrid Brett has sent Romero away in an effort to, as she says, not "be one of these bitches that ruins children" (TSAR 247). However a second motivation for this dismissal is at play. Brett tells Jake that Romero had been "ashamed" of her because she, in his eyes, did not meet his expectations of classic portrayals of feminine beauty. Brett says, "he wanted me to grow my hair out. Me, with long hair. I'd look so like hell" (TSAR 246). After Brett had acted in a motherly role towards him by dressing his wounds after he had fought Cohn, Romero expects her to fulfill other classic roles like wearing her hair long which would make her "more womanly." Brett, who was a nurse during the war, no longer wants to fulfill these roles. Much like she rejected Jake's advances to go out into the country together after she had sat by him in bed while he was ill, she now spurns Romero for asking the same of her. Brett either no longer feels comfortable or is willing to play these roles of doting nurse and long-haired matronly beauty. Where Romero has failed to accept Brett's status as the New Woman Jake has fully acclimated himself to her. Jake has ascended to a place where traditional female and male roles no longer 
matter and he, unlike earlier in the novel, no longer expects nor desires Brett to fulfill these traditional matronly roles.

This is why once out of the hotel room in Madrid Brett and Jake easily fall into their old habits, going to a café, eating a lavish meal and drinking wine, and when the novel ends they are once more locked together in a taxi, riding around a European city, only this time in an embrace, "The driver started up the street. I settled back. Brett moved close to me. We sat close against each other. I put my arm around her and she rested against me comfortably" (TSAR 251). Brett and Jake aren't apart as they were during their first taxi ride where Brett and he sit "like two strangers" rather they rest comfortably against one another, even in the hot summer sun that glistens off the white buildings of the city. Brett's excursion with Romero has not resulted in the death of love in the novel; rather, it has brought them back together once more.

The two rest comfortably against one another. Brett is no longer trembling as she was in the hotel. The day is bright and hot. An officer directing traffic raises his baton in phallic salute to the man who has the pretty girl in his arms and as the carriage stops he utters his famous last line, "isn't it pretty to think so?" This line, rather than limiting the idea of what might have been, illuminates a future never spoken of. Yes, they could have had such a "damned fine time 
together" but Jake's response is ambiguous towards only the past. The future is not deemed worthy of edification. Not only does the novel end, but the location that Jake tells the driver to head towards is never given, the future remains a mystery not only for the reader, but for Brett and Jake as well. In this instance for Brett and Jake the destination is not the answer, nor are there any answers, the only thing that matters is that at this very moment they are together, alone at last.

Thrust into a world of gendered social upheaval Brett and Jake spend the bulk of the novel attempting to evolve their own ideas of themselves into something that they can live with. This process of evolution leads directly to the culmination of the novel where Brett and Jake find themselves uniquely equipped to come together as the only couple that can survive the turbulence of The Sun Also Rises. Lady Brett Ashley, a member of the English aristocracy, forges headlong into her new role as the New Woman ideal, a woman who can stand beside the boys in their formerly off-limits social clubs, and hold her own in a world that is shifting before her very eyes. Jake Barnes spends the novel having already reclaimed his masculinity, but evolving that masculinity into a definition that works for him as a man who has been rendered emasculated by the effects of war. 
The single most significant factor that helps them on their way is each other. Throughout the novel Brett and Jake lean upon one another in an effort to stay stable in turbulent times. From taxi rides, to bedrooms, to bullfights and back into taxis, Brett and Jake work first as friends until they find the place where they can become a couple that exists despite the chaos of the world around them. Brett and Jake are not, as scholars and critics have claimed: doomed as lovers or interested only in savaging one another's ability to love. Quite inversely they are by novel's end the only pair of people left standing. Whatever the power of their missteps, the chaotic nature of both the time and the novel allows us no finality, and no closure. All that we as readers and scholars alike have is what Hemingway put on the page. The tale he weaves is not one of bitch-goddesses and defeated male protagonists. Rather it is a significant and early treatise on the ways in which gender and sexuality can transform two characters who are not only struggling against the pressure of still largely intact Victorian era rules of male and female engagement, but after finding themselves among the debris of World War I are carving out a new niche for themselves in a world that is settling around them. Brett and Jake's true legacy as literary characters comes not from the turmoil that exists throughout most of the novel but from the fact that in a world of social upheaval two 
characters can adjust to this rapid blending of social and gender rules, managing to wade through the wreckage of an era and find the balance to come together. 


\section{Works Cited}

Andrews Knodt, Ellen. "Diving deep: Jake's moment of truth at San Sebastian." The Hemingway Review. 17.1 (1997): 28 - 38. Print.

Fiedler, Leslie. "The Mythical Role of Lady Brett Ashley." Social Issues in Literature: Male and Female Roles in Ernest Hemingway's The Sun Also Rises. Detroit: Greenhaven Press. 2008. (91 - 96). Print.

Foucault, Michel. The History of Sexuality Volume I: An Introduction. New York: Vintage Books. 1990. Print.

Hemingway, Ernest. The Sun Also Rises. New York: Scribner. 2003. Print.

Hemingway, Ernest. "The Unpublished Opening of The Sun Also Rises." Antaeus 33 (Spring 79), 7. Print.

Martin, Wendy. "Brett Ashley as New Woman in The Sun Also Rises." Ernest Hemingway's The Sun Also Rises A Casebook. Linda Wagner-Martin ed. New York: Oxford University Press. 2002. (47-62). Print.

Spilka, Mark. "The Death of Love in The Sun Also Rises." Ernest Hemingway's The Sun Also Rises: A Casebook. Linda Wagner-Martin ed. New York: Oxford University Press (2002): 33 - 45. Print.

Wilson, Edmund. "The Sun Also Rises Criticizes Postwar Society." Social Issues in Literature: Male and Female Roles in Ernest Hemingway's The Sun Also Rises. Detroit: Greenhaven Press. 2008. (44 - 47). Print. 


\section{Works Consulted}

Articles in journals or collections:

Baskett, Sam S. "The Education of Jake Barnes." Social Issues in Literature: Male and Female Roles in Ernest Hemingway's The Sun Also Rises. Detroit: Greenhaven Press. 2008. (79 - 90) Print.

Buckley, JF. Echoes of closeted desire(s): The narrator and character voices of Jake Barnes." The Hemingway Review. 19.2 (2000): 73 - 88. Print.

Cheatham, George. "'Sign the Wire with Love': The Morality of Surplus in The Sun Also Rises." The Hemingway Review. 11.2 (1992) 25 - 30. Print.

Comley, Nancy R. and Robert Scholes. "The Complex Character of Lady Brett Ashley." Social Issues in Literature: Male and Female Roles in Ernest Hemingway's The Sun Also Rises. Detroit: Greenhaven Press. 2008. (108 114) Print.

Davidson, Arnold E., and Cathy N. Davidson. "Hemingway Challenges the Heroic "Code" in The Sun Also Rises." Social Issues in Literature: Male and Female Roles in Ernest Hemingway's The Sun Also Rises. Detroit: Greenhaven Press. 2008. (91 - 96). Print.

Eby, Carl. "'He felt the change so that it hurt him all through': Sodomy and transvestic hallucination in Hemingway." The Hemingway Review. 25.1 (2005): 77-98. Print.

Elliot, Ira. "Performance Art: Jake Barnes and "Masculine" Signification in The Sun Also Rises." American Literature. 67.1 (1995): 77 - 94. Print.

Fantina, Richard. "Hemingway's masochism, sodomy, and the dominant woman." The Hemingway Review. 23.1 (2003): 84 - 99. Print.

Ferrero, David. "Nikki Adams and the Limits of Gender Criticism." The Hemingway Review. 17.2 (1998): 18 - 31. Print. 
Fore, Dana. "Life unworthy of life?: Masculinity, disability, and guilt in The Sun Also Rises." The Hemingway Review. 26.2 (2007): 74 - 91. Print.

Forter, Greg. "Melancholy modernism: Gender and the politics of mourning in The Sun Also Rises." The Hemingway Review. 21.1 (2001): 22 - 38. Print.

Hyman, Peter. "Today's Real Men Are in Touch with Their Feminine Side." Social Issues in Literature: Male and Female Roles in Ernest Hemingway's The Sun Also Rises. Detroit: Greenhaven Press. 2008. (151 - 157) Print.

Kennedy, J. Gerald. “Hemingway's Gender Trouble." American Literature. 63.2 (1991): 187 - 207. Print.

Monteith, Moira. "A Change in Emphasis: Hemingway Criticism in Britain Over The Last Twenty-Five Years." The Hemingway Review. 1.2 1982) 2 - 19. Print.

Moreland, Kim. "Hemingway's Medievalist Impulse: Its Effect on the Presentation of Women and War in The Sun Also Rises." The Hemingway Review. 6.1 (1986) 30 - 41. Print.

Nolan Jr., Charles J. “Hemingway's Women's Movement.” The Hemingway Review. 3.2 (1984) 14 - 22. Print.

Onderdonk, Todd. "'Bitched': Feminization, Identity and the Hemingwayesque in The Sun Also Rises." Twentieth Century Literature. 52.1 (2006): 61 - 93. Print.

O'Sullivan, Sibbie. "Blended Gender Roles in The Sun Also Rises." Social Issues in Literature: Male and Female Roles in Ernest Hemingway's The Sun Also Rises. Detroit: Greenhaven Press. 2008. (79 - 90) Print.

Raabe, David M. "Hemingway's Anatomical Metonymies." Journal of Modern Literature. 23.1 (1999): 159 - 163. Print.

Rudat, Wolfgang E.H. "Sexual Dilemmas in The Sun Also Rises: Hemingway's Count and the Education of Jacob Barnes." The Hemingway Review. 8.2 (1989): 2 - 13. Print. 
Ryan, Dennis. “Dating Hemingway's Early Style/ Parsing Gertrude Stein's Modernism." Journal of American Studies. 29.2 (1995) 229 - 240. Print.

Sarason, Bertram. "Lady Brett Ashley and Lady Duff Twysden." Hemingway and The Sun Set. Sarason, Bertram. Ed. Washington DC: NCR/ Microcard Editions, 1972 pg $228-240$.

Vernon, Alex. "War, gender, and Ernest Hemingway." The Hemingway Review. 22.1 (2002): 34 - 58. Print.

Wagner-Martin, Linda. "Racial and Sexual Coding in Hemingway's The Sun Also Rises." The Hemingway Review. 10.2 (1991): 39 - 41. Print.

Watkins Fulton, Lorie. "The Nurturing Nature of Lady Brett Ashley." Social Issues in Literature: Male and Female Roles in Ernest Hemingway's The Sun Also Rises. Detroit: Greenhaven Press. 2008. (115 - 128). Print.

Wertheim, Stanley. "Images of Exile: The Portrait of a Lady and The Sun Also Rises." The Hemingway Review. 5.1 (1979): 25 - 27. Print.

Wright, Cuthbert. "The Bohemia of the Heart: Some Memories of the Lost Generation of the Twenties." The Sewanee Review. 41.2 (1933) $200-211$. Print.

Wylder, Delbert. "The Two Faces of Brett: The Role of the New Woman in The Sun Also Rises." Critical Essays on Ernest Hemingway's The Sun Also Rises. Nagel, James. Ed. London: Prentice Hall, 1995 pgs 89 - 94.

Books:

Bryfonski, Dedria, ed. Male and Female Roles in Ernest Hemingway's The Sun Also Rises. Detroit: Greenhaven Press, 2008. Print. Social Issues in Literature.

Lee, A R. Ernest Hemingway, New Critical Essays. London: Vision, 1983. Print.

Nagel, James. Critical Essays on Ernest Hemingway's The Sun Also Rises. New York: G.K. Hall, 1995. Print 
Spilka, Mark. Hemingway's Quarrel with Androgyny. Lincoln: U of Nebraska Press, 1990. Print.

Stoneback, H.R.. Reading Hemingway's The Sun Also Rises Glossary and Commentary. Kent, Ohio: The Kent State University Press. 2007. Print.

Wagner-Martin, Linda, ed. Ernest Hemingway's The Sun Also Rises: A Casebook. New York: Oxford University Press. 2002. Print.

Wagner-Martin, Linda, ed. Hemingway: Eight Decades of Criticism. East Lansing, MI: Michigan State University Press. 2009. Print.

Wagner-Martin, Linda. New Essays on The Sun Also Rises. Cambridge [Cambridgeshire: Cambridge University Press, 1987. Print. 